\title{
Geological features within the Big Indian Lake pluton, Hants County, Nova Scotia: evidence of igneous layering from recent diamond drilling
}

\author{
M.C. Corey \\ Nova Scotia Department of Natural Resources, P.O. Box 698, Halifax, Nova Scotia B3J 2T9, Canada
}

\author{
Date Received January 7, 1992 \\ Date Accepted March 9, 1992
}

\begin{abstract}
This paper describes geological features observed in diamond drill core recovered from three holes in the Big Indian Lake pluton near the eastern margin of the South Mountain Batholith. The pluton is comprised of four texturally variable granitic facies (order of decreasing abundance): (1) megacrystic to equigranular monzogranite and leucomonzogranite, (2) porphyritic biotite monzogranite, (3) equigranular leucomonzogranite, and (4) microgranite. Evidence of igneous layering observed in drill core includes: (1) the presence of a cumulate-like aggregate of plagioclase, (2) centimetre-thick layers modally enriched in biotite and apatite, and (3) gradational contacts between granitic rock-types. The plagioclase aggregate contains 50 to $90 \%$ zoned and generally equidimensional plagioclase crystals which commonly have mutually interfering grain boundaries and a poikilitic texture characterized by abundant biotite inclusions. Contacts of the plagioclase aggregate with other facies of the pluton are generally gradational, and marked by a progressive increase in biotite and decrease in euhedral plagioclase crystals.

The amount of plagioclase-rich aggregate decreases with depth in the drill core, and granodiorite and biotite monzogranite become more abundant. They grade into predominately leucomonzogranite and microgranite at depth. The microgranite is typically of syenogranite composition and closely associated with several types of alteration and mineralization. The common occurrence of pegmatite within the microgranite at boundaries with equigranular leucomonzogranite suggests that the microgranite crystallized from a highly fractionated, water-saturated liquid. The microgranite may represent a texturally and mineralogically modified leucomonzogranite rather than a primary magmatic product.
\end{abstract}

The occurrence of what appears to be primary magmatic layering in the Big Indian Lake pluton appears to confirm the relevance of applying fractional crystallization models to the South Mountain Batholith.

Cet article décrit les caractéristiques géologiques de trois forages dans le pluton du lac Big Indian, près de la bordure est du batholite du mont South. Le pluton est composé de quatre faciès granitiques de diverses textures (en ordre d'abondance décroissante): (1) des monzogranites et leucomonzogranites à mégacristaux ou équigranulaires, (2) des monzonites porphyriques à biotite, (3) des leucomonzogranites équigranulaires et (4) des microgranites. Les indications de litage magmatique observées en forage sont: (1) la présence d'un aggrégat de plagioclase semblable à un cumulat, (2) des lits centimétriques enrichis en biotite et en apatite et (3) des contacts graduels entre les types de granite. L'aggrégat de plagioclase contient de 50 à $90 \%$ de cristaux de plagioclase zonés et généralement trapus qui ont communément des contacts engrenés et une texture poecilitique avec d'abondantes inclusions de biotite. Les contacts de l'aggrégat de plagioclase avec les autres faciès du pluton sont généralement graduels et sont soulignés par un enrichissement progressif en biotite et un appauvrissement en cristaux de plagioclase euédriques.

La proportion d'aggrégat riche en plagioclase décroît avec la profondeur tandis que la granodiorite et le monzogranite à biotite deviennent plus abondants. Le microgranite a typiquement une composition de syénogranite et est intimement associé à de l'altération et de la minéralisation. L'abondance de pegmatite au sein du microgranite en contact avec les leucomonzogranites équigranulaires suggère que le microgranite a cristallisé à partir d'un magma très différencié et saturé en eau. Le microgranite pourrait représenter un leucomonzogranite dont la texture et la minéralogie ont été modifiées plutôt qu'un produit magmatique primaire.

Le présence de ce qui est apparemment un litage magmatique primaire dans le pluton du lac Big Indian semble confirmer la pertinence des modèles de cristallisation fractionnée pour le batholite du mont South.

[Traduit par le journal]

\section{INTRODUCTION}

This paper presents the results of diamond drilling conducted by the Nova Scotia Department of Natural Resources (formerly Mines and Energy) during the period September 1989 to January 1990. The drill holes are located within Hants County, approximately $40 \mathrm{~km}$ northwest of Halifax, ATLANTIC GEOLOGY 28, $51.62(1992)$ near the eastern margin of the South Mountain Batholith (Fig. 1). The holes are situated in an area of the batholith consisting of a polyphase suite of monzogranite referred to as the Big Indian Lake pluton. This pluton has previously been referred to as the Big Indian Polyphase Intrusive Complex (Kontak and Corey, 1988) and the Big Indian Lake Polyphase Intrusive Suite (Corey, 1988; Corey and Chatterjee, 1990). The 


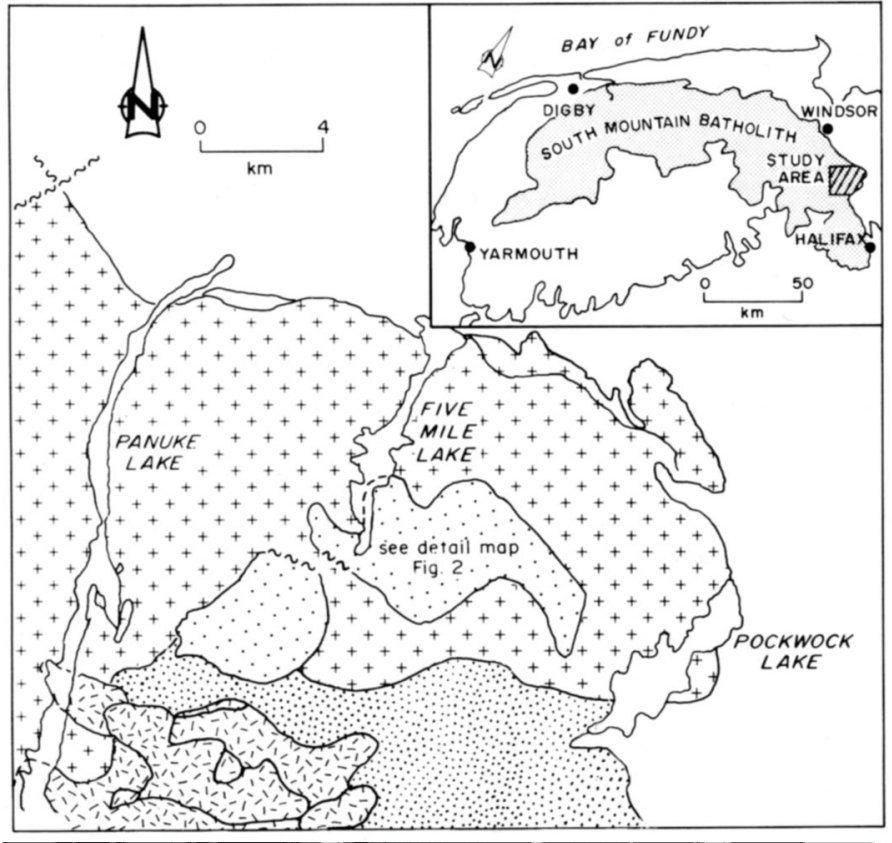

LEGEND

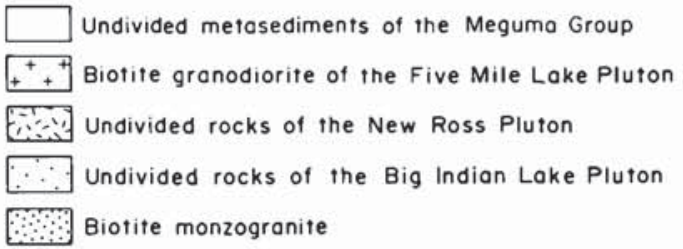

Fig. 1. Map showing location of the Big Indian Lake pluton.

name change was required to be consistent with terminology utilized by MacDonald et al., 1992.

Three holes having a cumulative depth of $776 \mathrm{~m}(2546 \mathrm{ft})$ were drilled in order to investigate various mineralogical and geological features of the pluton (Corey and Chatterjee, 1990). This paper begins by briefly summarizing the results of previous studies within this pluton and then continues with a description of geological features observed within the drill core including textural evidence of igneous layering embodied by the presence of cumulate-like aggregates of plagioclase, biotite and apatite. The only other evidence of igneous layering within the South Mountain Batholith is the occurrence of rhythmic layering of biotite and K-feldspar megacrysts within the Halifax pluton near Chebucto Head which are thought to reflect local differential shear within the magma during ascent (Smith, 1975; Abbot, 1989).

The drill core is stored at the Department of Natural Resources core library facilities in Stellarton, Nova Scotia.

\section{General Geology and Previous Work}

The Big Indian Lake pluton is comprised of two separate 18 to $20 \mathrm{~km}^{2}$ bodies which intrude medium- to coarsegrained, equigranular, biotite granodiorite ( \pm tonalite) of the Five Mile Lake pluton (Corey, 1986; Ham and Horne, 1986;
Horne et al., 1991). The Big Indian Lake pluton is the second smallest of the thirteen plutons which have been delineated within the peraluminous South Mountain Batholith based on systematic 1:50,000 geological mapping and lithogeochemistry. A thorough description of the various plutons is provided by MacDonald et al., 1992.

The angular shape of the eastern lobe of the pluton, together with zones of intense shearing both at the contacts and internally, indicates that faulting occurred throughout and perhaps even controlled emplacement of the pluton. Furthermore, the presence of several well-exposed northwest trending, steeply dipping faults which separate the two lobes of the pluton suggest that at one time the lobes were attached (Fig. 1).

Based on detailed mapping of outcrop the Big Indian Lake pluton has been divided into four mineralogically similar but texturally variable granitic facies (Fig. 2). In order of decreasing abundance these are: (1) K-feldspar megacrystic, muscovite + biotite monzogranite; (2) microgranite (fine- to very fine-grained with $<2 \%$ mafic minerals); (3) medium- to slightly coarse-grained, equigranular to porphyritic, biotite monzogranite; and (4) medium- to slightly coarse-grained, equigranular, muscovite + biotite leucomonzogranite (2-6\% mafic minerals). The above facies are characterized by containing variable amounts of the hyperaluminous mineral assemblage, biotite \pm muscovite \pm garnet \pm cordierite \pm andalusite \pm sillimanite (Kontak and Corey, 1988; Corey, 1988). In addition to the above, two outcrops of a plagioclase-rich aggregate occur, which are characterized by abundant euhedral plagioclase grains surrounded by a finer-grained groundmass composed of albite, biotite, apatite, K-feldspar, quartz and lesser chlorite, cordierite and muscovite (Fig. 2). This rock type is thought to represent a cumulate based on textural features which are discussed below. In outcrop these facies show sharp irregular contacts and, with the exception of the microgranite, contain granodiorite xenoliths.

The granodiorite xenoliths are predominately mediumto coarse-grained, slightly megacrystic $(<10 \%)$ and contain 12 to $18 \%$ biotite. These features are consistent with those shown by granodiorite occurring within the Five Mile Lake pluton. These xenoliths in turn contain numerous biotiterich, metasedimentary (?) xenoliths of variable size $\left(<10 \mathrm{~m}^{2}\right)$, shape and degree of assimilation. The proposed cumulate is the only facies of the Big Indian Lake pluton to contain what appear to be metasedimentary xenoliths.

Field observations together with previous petrological and geochemical investigations indicate that the rocks of the Big Indian Lake pluton have undergone considerable late- to post-magmatic mineralogical and textural modification in response to successive and superimposed metasomatism (Corey and Chatterjee, 1990). An example of this is represented by the ubiquitous occurrence of spessartine-rich (1527 mole \%) garnets which are exclusive to rocks of this pluton within the batholith. The garnets display an antipathetic relationship with biotite and a metasomatic origin has been suggested (Kontak and Corey, 1988). Other alteration effects listed in decreasing magnitude include $\mathrm{K}$-feldpathization 


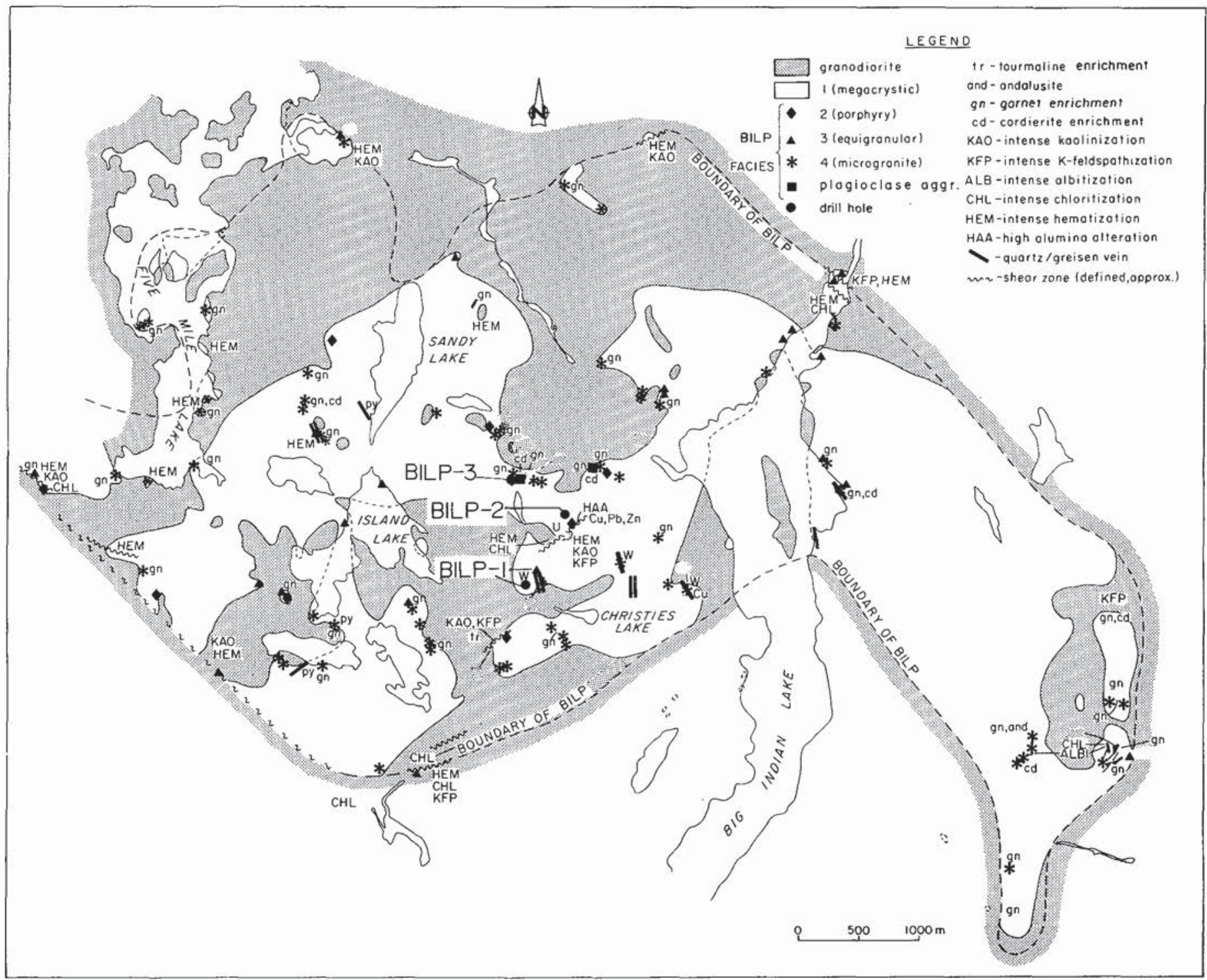

Fig. 2. Detailed geology map of a portion of the eastern lobe of the Big Indian Lake pluton showing location of diamond drill holes.

(which appears to have been synchronous with garnet formation), albitization, sericitization, silicification, hematization, chloritization and high-alumina alteration. The latter is manifested by the presence of abundant andalusite with muscovite, pyrite and trace amounts of sillimanite and hercynitic spinel (Corey, 1988). Although the effects of the above alteration are present in all facies, they are most intense within and proximal to the microgranite. This is particularly true for the occurrence of garnet and K-feldpathization. The intensity of the latter is indicated by microgranite samples which are of syenogranite composition.

This close spatial association of alteration with the microgranite suggests that the alteration effects may be attributed to interaction with fluids exsolved from the microgranite. Several types of mineralization also show a close spatial association with the microgranite. These include: (1) wolframite-bearing en echelon quartz veins, (2) chloritealbite-tourmaline-bearing greisen veins, and (3) pyrite-chalcopyrite-bearing quartz-muscovite greisen pods. Minor, uranyl-phosphate mineralization associated with intense he- matization also occurs within the pluton and is restricted to a northeast-trending fault zone (Fig. 2). Not related to the uranium mineralization, but also fault-controlled, are small pods $\left(<20 \mathrm{~cm}^{2}\right)$ of massive, black tourmaline. Field observations indicate that early pervasive types of alteration and mineralization such as garnet and greisen pod development are overprinted by later fracture-controlled types such as high-alumina alteration and uranyl-phosphate mineralization (Corey, 1988).

The average concentration of major and trace elements within outcrop samples of each facies of the pluton are presented in Tables 1 and 2, respectively. These analyses are compiled from Corey and Chatterjee (1990) which presents a detailed account of the geochemistry of the Big Indian Lake pluton and the various alteration facies. The geochemistry suggests that the biotite monzogranite facies is the least differentiated and the microgranite is the most differentiated facies within the Big Indian Lake pluton. As can been seen in Table 1, differentiation is characterized by increasing $\mathrm{SiO}_{2}$, and decreasing $\mathrm{Fe}_{2} \mathrm{O}_{3}, \mathrm{MgO}$ and $\mathrm{TiO}_{2}$, which roughly coin- 
Table 1. Average concentration of major-oxides and element ratios within each facies of the Big Indian Lake pluton (compiled from Corey and Chatterjee, 1990).

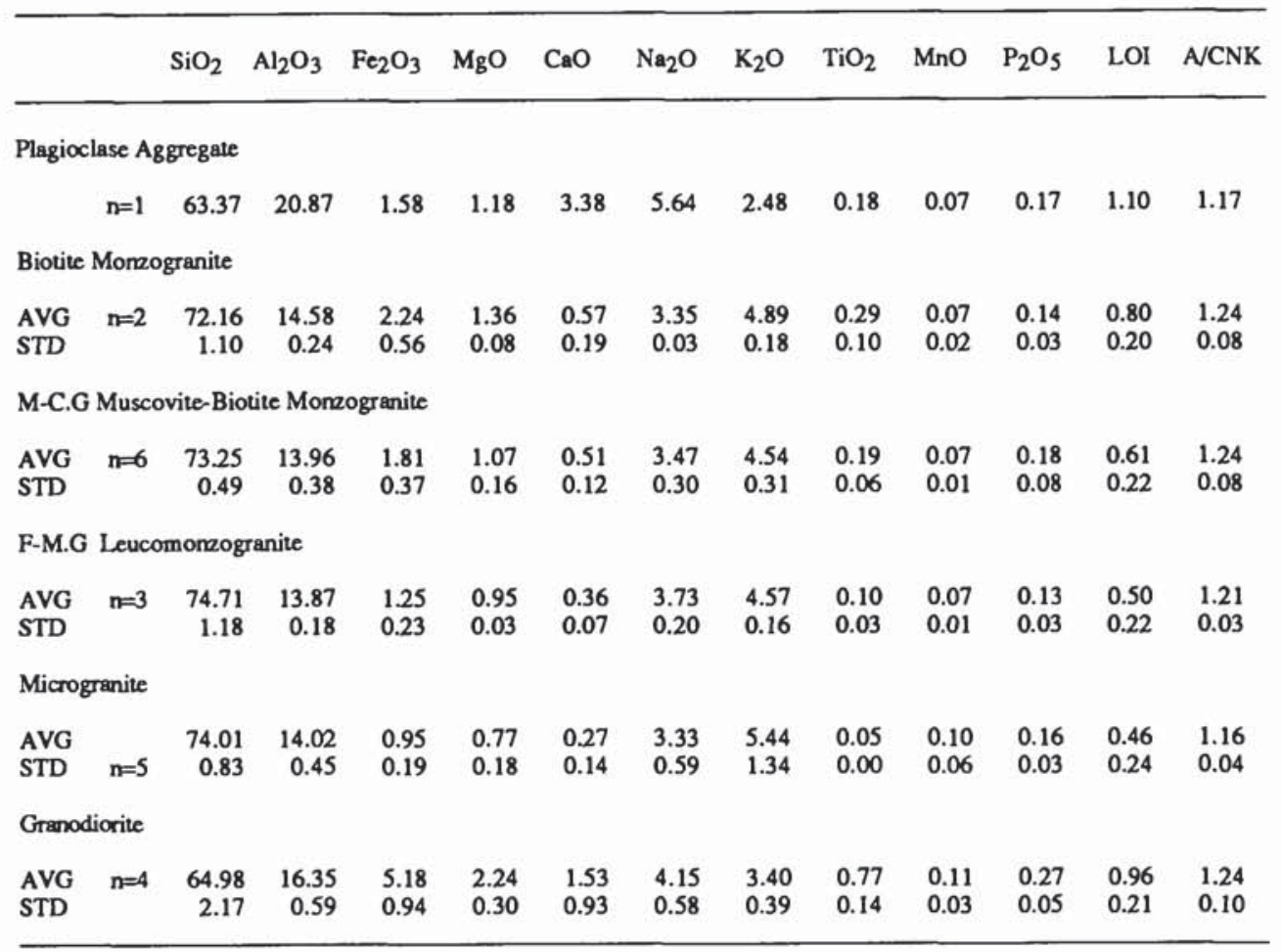

Table 2. Average concetration of trace elements within each facies of the Big Indian Lake pluton (compiled from Corey and Chatterjee, 1990).

\begin{tabular}{|c|c|c|c|c|c|c|c|c|c|c|c|c|c|c|c|c|c|c|c|c|}
\hline & $\mathrm{Ba}$ & $\mathbf{R b}$ & $\mathrm{Sr}$ & $\mathbf{Y}$ & $Z_{x}$ & $\mathrm{Nb}$ & $\mathrm{Ta}$ & $\mathrm{Pb}$ & $\mathrm{Zn}$ & $\mathrm{Cu}$ & Th & $\mathrm{U}$ & $\mathrm{F}$ & Au-ppb & B & $\mathrm{Li}$ & $\mathrm{Sc}$ & Mo & w & Sn \\
\hline \multicolumn{21}{|c|}{ Plagioclase-Rich Aggregate } \\
\hline & 216.00 & 135.00 & 294.00 & 15.00 & 101.00 & 10.00 & 1.80 & 23.00 & 42.00 & 0.00 & 4.40 & 1.40 & 400.00 & 10.00 & 30.00 & 41.00 & 3.70 & 0.00 & 5.00 & 10.00 \\
\hline \multicolumn{21}{|c|}{ Biotite Monzogranite } \\
\hline AVG & 442.50 & 186.50 & 100.00 & 21.00 & 104.50 & 8.50 & 0.75 & 23.50 & 46.00 & 0.00 & 10.30 & 3.40 & 380.00 & 5.00 & 25.00 & 44.00 & 4.90 & 1.00 & 2.50 & 8.00 \\
\hline STD & 59.50 & 14.50 & 19.00 & 4.00 & 32.50 & 1.50 & 0.25 & 1.50 & 10.00 & 0.00 & 4.70 & 0.70 & 90.00 & 3.00 & 5.00 & 9.00 & 1.40 & 0.00 & 0.50 & 0.00 \\
\hline \multicolumn{21}{|c|}{ M-C.G Muscovite-Biotite Momzogranite } \\
\hline AVG & 222.13 & 200.50 & 48.88 & 18.88 & 70.88 & 9.25 & 1.80 & 23.75 & 40.13 & 2.38 & 8.66 & 18.25 & 0.75 & 9.38 & 25.75 & 2.25 & 5.98 & 15.38 & 25.63 & 45.63 \\
\hline STD & 83.12 & 38.29 & 17.12 & 4.23 & 17.65 & 2.28 & 1.05 & 7.33 & 14.30 & 2.54 & 1.28 & 2.28 & 87.00 & 8.35 & 7.26 & 12.85 & 0.95 & 0.83 & 0.93 & 3.00 \\
\hline \multicolumn{21}{|c|}{ F-M.G Leucomomogranite } \\
\hline AVG & 83.67 & 177.33 & 20.00 & 16.67 & 45.67 & 6.67 & 0.80 & 20.33 & 27.67 & 2.00 & 3.63 & 3.43 & 181.67 & 4.00 & 23.33 & 35.67 & 2.67 & 2.00 & 1.00 & 10.33 \\
\hline STD & 37.72 & 44.90 & 6.48 & 3.77 & 11.12 & 1.25 & 0.59 & 5.31 & 5.44 & 2.83 & 0.90 & 1.16 & 80.66 & 0.00 & 2.36 & 8.22 & 0.83 & 0.00 & 0.00 & 3.09 \\
\hline \multicolumn{21}{|c|}{ Microgranite } \\
\hline AVG & 105.60 & 189.80 & 19.20 & 16.80 & 42.40 & 4.80 & 0.50 & 25.20 & 28.80 & 6.60 & 3.08 & 4.72 & 79.60 & 12.00 & 20.00 & 33.40 & 2.86 & 1.80 & 1.20 & 7.40 \\
\hline STD & 79.42 & 49.37 & 11.97 & 4.53 & 24.81 & 1.83 & 0.46 & 10.30 & 5.98 & 5.54 & 2.18 & 2.77 & 13.44 & 8.46 & 3.16 & 23.88 & 1.49 & 0.98 & 1.17 & 2.42 \\
\hline \multicolumn{21}{|c|}{ Granodiorite } \\
\hline AVG & 644.80 & 158.20 & 198.60 & 29.40 & 220.00 & 13.60 & 1.12 & 14.80 & 74.60 & 7.80 & 13.60 & 3.28 & 656.00 & 17.75 & 28.00 & 58.20 & 10.20 & 0.00 & 0.60 & 4.40 \\
\hline STD & 150.07 & 27.79 & 48.54 & 6.15 & 43.25 & 1.36 & 0.23 & 7.98 & 40.14 & 4.75 & 1.50 & 0.81 & 145.96 & 18.67 & 16.31 & 40.32 & 5.15 & 0.00 & 0.80 & 4.27 \\
\hline
\end{tabular}

cides with a decrease in modal biotite from $>12$ to $<2 \%$. The proposed cumulate sample is characterized by low $\mathrm{SiO}_{2}$ and $\mathrm{K}_{2} \mathrm{O}$ and high $\mathrm{Al}_{2} \mathrm{O}_{3}, \mathrm{CaO}$ and $\mathrm{Na}_{2} \mathrm{O}$ concentrations. With respect to REE concentrations, the above differentiation sequence is marked by a progressive depletion of total REEs,
LREEs and Eu (Fig. 3). The marked heavy REE enrichment within the altered microgranite samples is thought to reflect a higher modal concentration of metasomatic garnet. The plagioclase-rich aggregate has a total REE concentration of $80 \mathrm{ppm}$ and a positive Eu anomaly (Eu/Eu* $=1.9$; Fig. 3). 


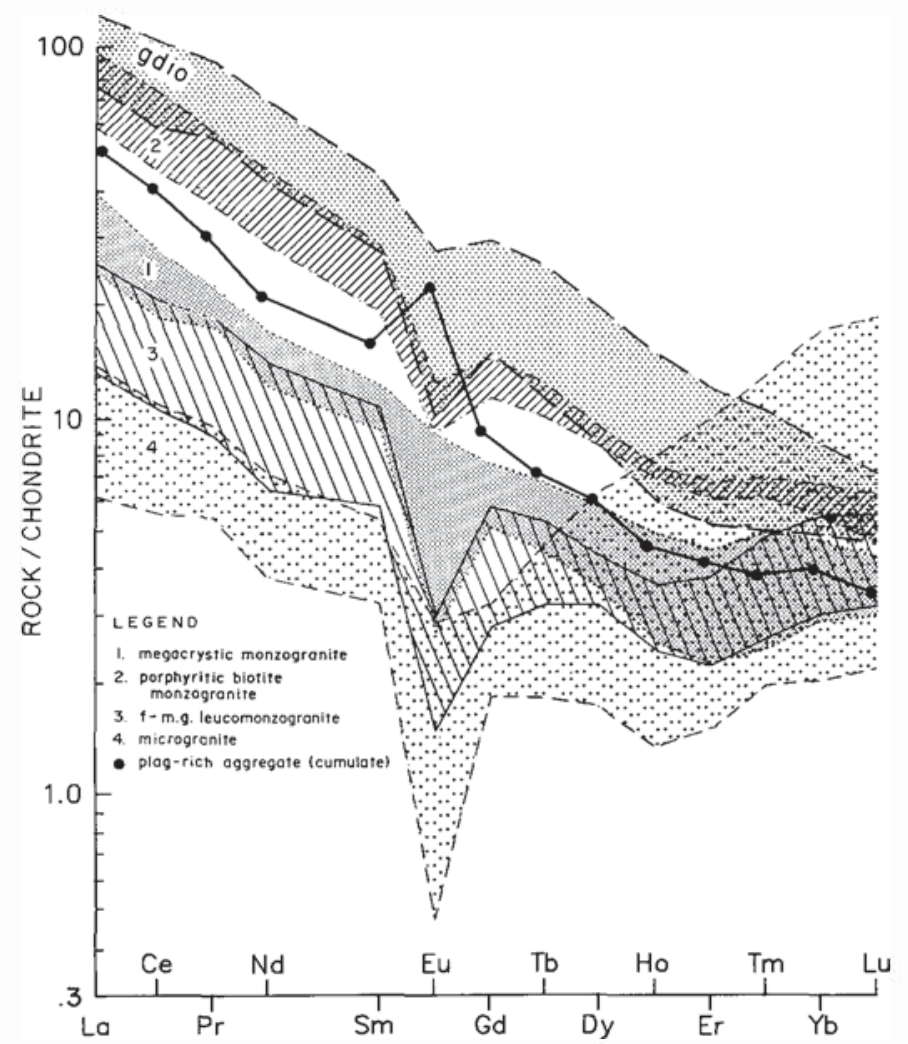

Fig. 3. Range of normalized REE concentrations within facies of the Big Indian Lake pluton and granodiorite (gdio). Refer to Figure 2 for identification of facies number. Superimposed on these fields is the normalized REE pattern of a plagioclase-rich aggregate sample.

\section{Description of Drill Core}

\section{DDH-BILP-1}

This hole, collared within leucomonzogranite, was drilled

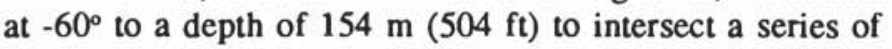
wolframite-bearing en echelon quartz veins hosted by microgranite (Fig. 2). A simplified, representative section of this hole is shown in Figure 4. Overall, the drill core consists of $41 \%$ leucomonzogranite, $43 \%$ granodiorite, $10 \%$ biotite monzogranite, $3 \%$ muscovite-biotite monzogranite and 3\% microgranite. The leucomonzogranite is commonly pink to deep orange in colour, containing 4 to $6 \%$ modal biotite with local enrichment of up to $8 \%$ biotite. Texturally this facies is fine- to coarse-grained and moderately equigranular to slightly porphyritic. The most reliable way to discriminate between the fine-grained textured leucomonzogranite and the microgranite is that the latter contains ubiquitous garnet. The leucomonzogranite displays variable degrees of pervasive and fracture-controlled silicification, chloritization, hematization and kaolinization. Where alteration is most intense, the leucomonzogranite is commonly vuggy and intensely fractured/sheared. Although this facies generally contains only trace amounts of garnet, marked garnet enrichment was noted within zones of pervasive silicification and chloritiza- tion of biotite. This is contrary to previous observations within the microgranite which suggest garnet development accompanied K-feldspathization. In contrast to the leucomonzogranite, the microgranite is characterized by abundant garnet. It is interesting to note that while garnet in surficial exposures of microgranite is accompanied by a distinct biotite-free halo (Kontak and Corey, 1988), many of the garnets in the core contain biotite inclusions.

Microgranite-leucomonzogranite contacts are commonly marked by pegmatite. The only exception noted was where a dramatic increase in modal garnet occurred within microgranite at a contact with a fine-grained section of leucomonzogranite. This hole intersected only minor microgranite which was surprising due to the amount of microgranite outcrop in the immediate area and, together with the above contact features, suggests that this facies may be derived from metasomatic rather than magmatic processes. The next most abundant facies encountered during drilling was a medium- to coarse-grained, moderately equigranular granodiorite which varied from $<0.5$ to $30 \mathrm{~m}$ thick. Contacts of this facies with the other facies are sharp or sheared.

In contrast to the predominance of brittle deformation within the leucomonzogranite, deformation within the granodiorite is dominated by ductile features such as C-S fabrics and chloritic mylonite bands (Fig. 5a). These bands are $<1 \mathrm{~cm}$ wide and commonly oriented at $<30^{\circ}$ to the core axis. Although not shown in Figure $4 \mathrm{a}$, a similarly oriented, $1 \mathrm{~m}$ wide brittle-ductile shear zone was intersected $134 \mathrm{~m} \mathrm{(440} \mathrm{ft)}$ down-hole. These structures are similar in orientation to a fault which outcrops to the immediate north (see Fig. 2) which trends approximately north-south and dips steeply to the east. Intense chloritization of biotite and saussuritization of plagioclase accompany zones of intense deformation.

Although this hole intersected several narrow quartz veins, none contain the wolframite-scheelite mineralization observed within the en echelon quartz veins. This suggests that either the latter veins pinch out with depth or that tungsten mineralization is erratic. It is probably significant that while the surficial veins are hosted by microgranite the veins in the drill core occur predominately within leucomonzogranite.

\section{DDH-BILP-2}

This hole [drilled at $-60^{\circ}$ for $152 \mathrm{~m}(498 \mathrm{ft})$ ] was positioned to intersect a northeast trending shear zone which is of interest since it appears to have been a conduit for successive and superimposed hydrothermal alteration, particularly the occurrence of high-alumina alteration (Corey, 1988). Also focused along the shear zone, but not seen in drill core, is disseminated uranyl-phosphate mineralization (see above). Representative sections of this hole are shown in Figure 4. Biotite monzogranite was the most abundant $(60 \%)$ facies intersected followed by leucomonzogranite $(15.5 \%)$, microgranite $(12.5 \%)$ and granodiorite (12\%). The biotite monzogranite is predominately medium- to coarse-grained, moderately equigranular in texture and contains 8 to $12 \%$ 
BILP-I Drill Section

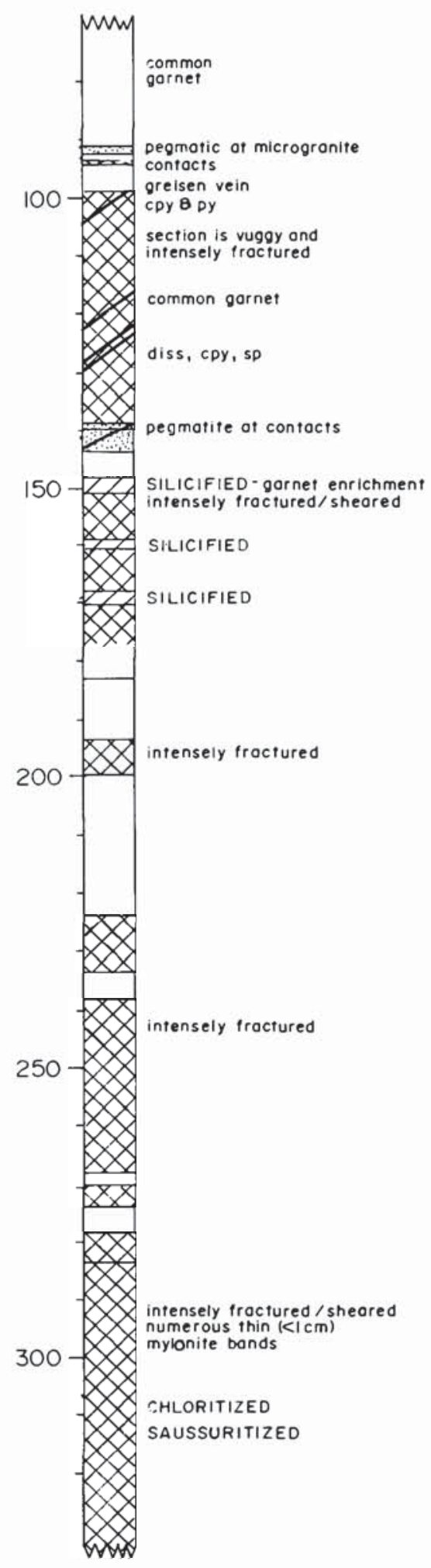

BILP - 2 Drill Section

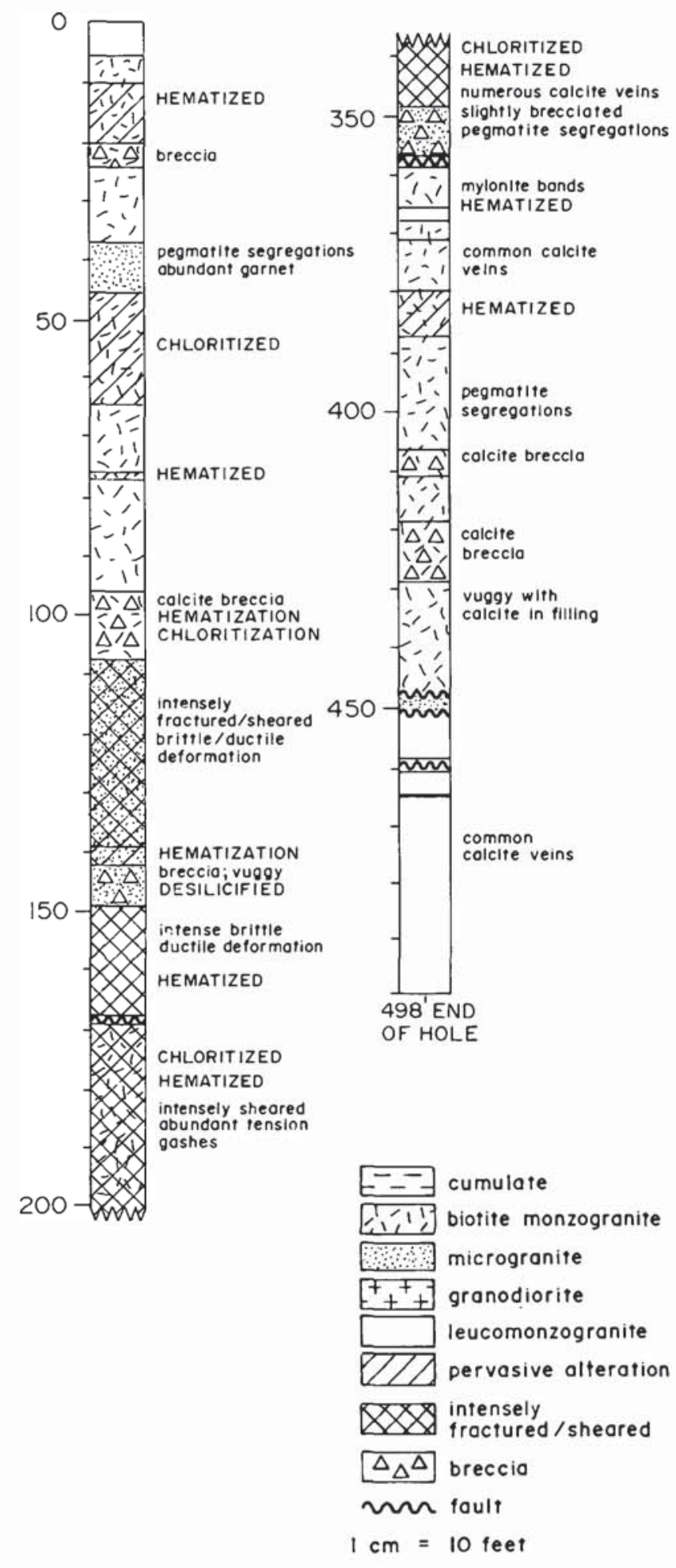

Fig. 4. Representative core sections from BILP-1 and BILP-2 drill holes.

biotite. Although the types and styles of alteration and deformation present in this hole are similar to those observed in BILP-1, there are some significant differences. For example, in contrast to BILP-1 where ductile features were largely restricted to the granodiorite, this core shows ductile effects in all facies; a feature which is probably related to proximity 

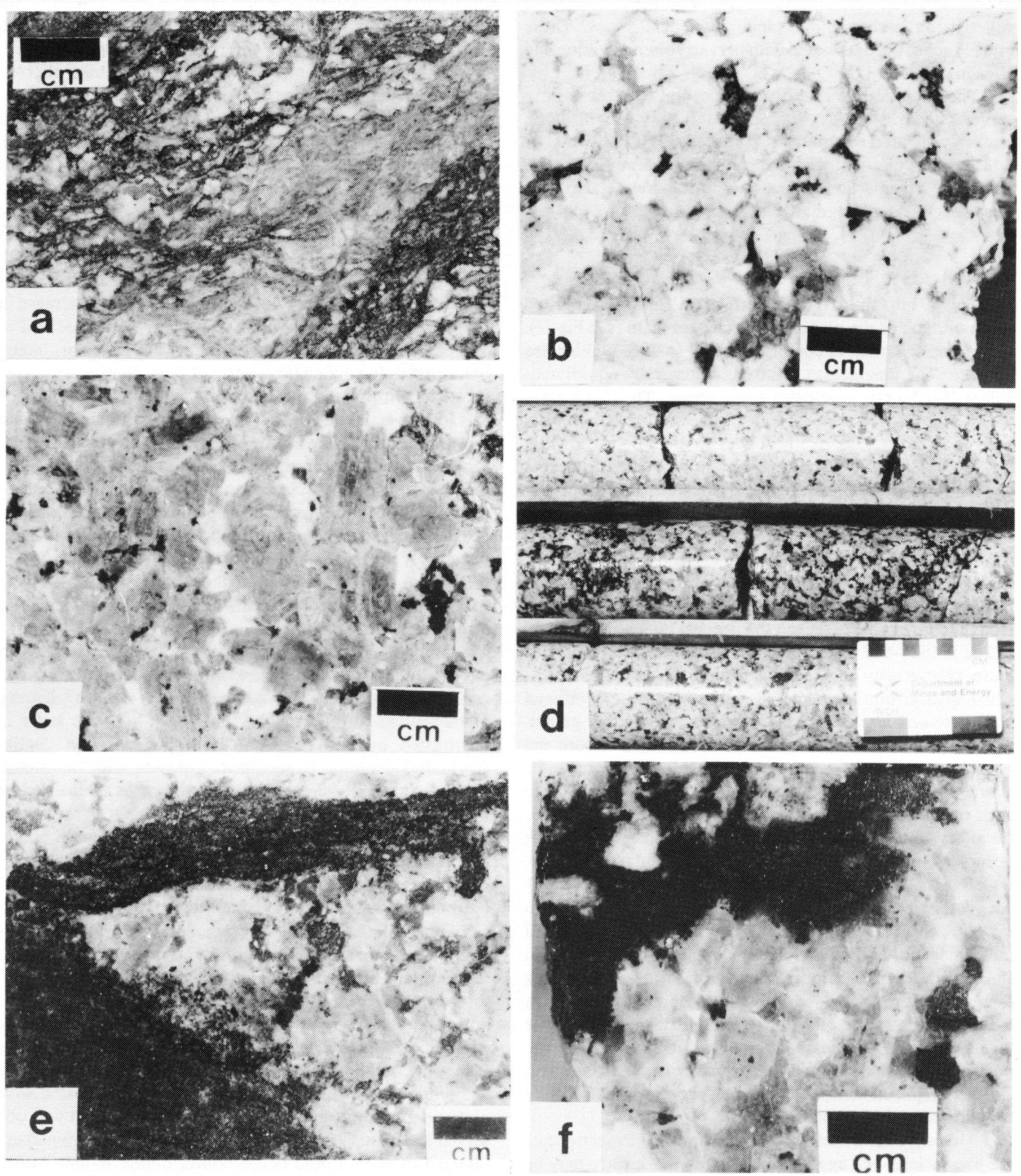

Fig. 5. (a) Core sample of granodiorite showing ductile deformation commonly characterized by C-S fabric and chloritic mylonite bands. (b) Close-up of plagioclase-rich aggregate showing poikilitic biotite with interstitial quartz and coarse-grained biotite. (c) Sample of plagioclase-rich aggregate showing intense blue-grey colouration of plagioclase crystals. White, opaque, interstitial mineral is albite. (d) Example of discrete, modally-enriched layers of coarse-grained biotite which occur in the plagioclase-rich aggregate. (e) Section of plagioclase-rich aggregate containing typical biotite-rich, metasedimentary looking xenoliths. The top xenolith has a vertical orientation, parallel to the core axis. (f) Core sample showing dark apatite-rich layer at contact of plagioclase aggregate (below layer) and biotite monzogranite. 
to the fault zone. Calcite is also more abundant, infilling vugs and tension gashes and cementing breccia zones. These breccia zones are associated with pervasive hematization and chloritization.

The microgranite also contains several features not observed in BILP-1. Of particular interest is a $3 \mathrm{~m}$ wide, intensely sheared section at $106 \mathrm{~m}(348-357 \mathrm{ft})$ which contains angular clasts of what appear to be sheared leucomonzogranite. This particular section of microgranite also contains several small pegmatite segregations.

\section{DDH BILP-3}

This $471 \mathrm{~m}$ (1544ft) deep, vertical drill hole was collared on an outcrop of the plagioclase-rich aggregate (see Fig. 2). In outcrop this rock is comprised of 75 to $90 \%$ plagioclase euhedra. The plagioclase crystals are generally equidimensional $(1-1.5 \mathrm{~cm})$, interlocking and zoned. The plagioclase varies in colour from a clear translucent white, chalky white, light to dark grey, mauve and light to medium green (Fig. $5 \mathrm{~b}, \mathrm{c})$. Representative sections of core recovered from this drill hole are shown in Figure 6. Besides the proposedcumulate rock which comprises $18 \%$ of the recovered core, drilling intersected $44 \%$ granodiorite, $24.5 \%$ biotite monzogranite, $13 \%$ leucomonzogranite and $0.5 \%$ microgranite. Intersections of the plagioclase-rich aggregate ranged from $<1$ to $44 \mathrm{~m}$ (1-145 ft) thick. The thickest section occurred from 3 to $46 \mathrm{~m}(9-154 \mathrm{ft})$ and the deepest intersection at 189 to $202 \mathrm{~m}$ (624-667 ft) (see Fig. 6). Besides abundant plagioclase, petrography on a surficial sample of this facies indentified quartz, biotite, albite, K-feldspar, apatite, pinitized cordierite and less common muscovite, sphene and garnet. The latter mineral was only rarely seen in the drill core and occurs as small euhedra $(<5 \mathrm{~mm})$ within plagioclase crystals. The sharp angular habit of the interstitial minerals attests to their crystallizing in open vugs (pores) between the plagioclase crystals. While staining for $\mathrm{K}$-feldspar indicates it occurs exclusively as a fine-grained interstitial phase, albite, which has a white-opaque appearance, occurs as small $(<1$ $\mathrm{cm}$ ), interstitial euhedra and as an adcumulate mantle upon many of the plagioclase crystals. Biotite occurs as small inclusions within the plagioclase crystals and as interstitial flakes. While modal biotite concentration is generally less than $6 \%$ within this facies, it does occur in biotite-rich ( $\leq 50 \%$ ) bands 2 to $10 \mathrm{~cm}$ wide (Fig. $5 \mathrm{~d}$ ). The biotite in these bands is black and coarse-grained $(\leq 1.0 \mathrm{~cm})$ raising the possibility that it also represents primary magmatic layering. Cordierite, pseudomorphed by pinite, occurs as small blocky euhedra interstitial to other crystals.

Although not evident from the photos, intersections of the plagioclase-rich aggregate closest to the surface may be vuggy (see Fig. 6). The presence of friable and pitted quartz within these vuggy zones suggests that the vugs represent areas of quartz dissolution. Discrete zones of kaolinization, saussuritization, K-feldspathization and desilicification occur to a variable degree within all intersections of this facies. The least altered section of plagioclase-rich aggregate at 175 $\mathrm{m}(575 \mathrm{ft})$ is characterized by well zoned, clear, translucent plagioclase euhedra with only minor interstitial mineral growth $(<10 \%)$.

Discrete zones containing abundant xenoliths are also present within the plagioclase-rich aggregate, with the section from 35 to $47 \mathrm{~m}$ (115-155 ft) containing the greatest concentration of xenoliths. The xenoliths are biotite-rich, range in size from 1 to $5 \mathrm{~cm}^{2}$ and are often oriented normal to the core axis (Fig. 5e). Xenoliths were also commonly found at or near contacts between the plagioclase-rich aggregate and granodiorite, whereas they rarely occur at contacts with other facies. Contacts of the plagioclase-rich aggregate with other pluton-facies are usually gradational, being characterized by a decrease in plagioclase crystals and an increase in interstitial biotite. An unusual contact feature observed at $190 \mathrm{~m}(624 \mathrm{ft})$ was the presence of a $1 \mathrm{~cm}$ wide dark-green band containing abundant, small $(<1 \mathrm{~mm})$ apatite crystals at a contact with biotite monzogranite (Fig. $5 f$ ). The origin of this feature is unknown, but it may reflect similar layering to that which formed the biotite-rich bands.

Although the occurrence of biotite-rich layers are common within the plagioclase-rich aggregate, they are not restricted to it. Similar bands are also observed within granodiorite and biotite monzogranite. Within the granodiorite these bands may reach up to $75 \%$ biotite and exhibit a noticeable foliation at approximately $40^{\circ}$ to the core axis. It is interesting to note that several zones characterized by biotite-depletion also occur within the granodiorite.

Granodiorite intersections in the hole ranged from $<1$ to $52 \mathrm{~m}(2-170 \mathrm{ft})$ in thickness and although they have a consistent texture (see above) they do reflect varying degrees of chloritization, hematization and shearing. The latter is manifested by both brittle (calcite-breccia) and ductile (mylonite) features. Granodiorite contacts with the pluton facies are normally sharp, and in several cases are marked by biotite enrichment. In one instance, a contact with biotitemonzogranite was defined by a narrow aplite dyke, which may reflect late- to post-magmatic infiltration of fluids along lithological contacts. The granodiorite often contains small $\left(<10 \mathrm{~cm}^{2}\right)$ metasedimentary xenoliths.

Other pluton facies intersected include biotite monzogranite, minor leucomonzogranite and minor microgranite. Intersections of biotite monzogranite are medium- to coarsegrained, slightly megacrystic $(<5 \%)$ to porphyritic in texture. Although garnet is typically rare to absent within this facies in drill holes 1 and 2 , some intersections in this core contain numerous, small $(<3 \mathrm{~mm})$ garnet grains in both plagioclase and biotite and also within narrow sections associated with biotite depletion. An unusual occurrence of garnet was observed at $237 \mathrm{~m}(779 \mathrm{ft})$ where several large $\left(1 \mathrm{~cm}^{2}\right)$ garnets intergrown with biotite occur within biotite monzogranite adjacent to the contact with pegmatite-bearing microgranite. The presence of several different styles of garnet implies distinct modes of formation. Also present in some sections of biotite monzogranite are narrow $(<10 \mathrm{~cm})$ layers of plagioclase-rich aggregate and granodiorite (Fig. 6). Contacts of biotite monzogranite with other pluton facies are usually 

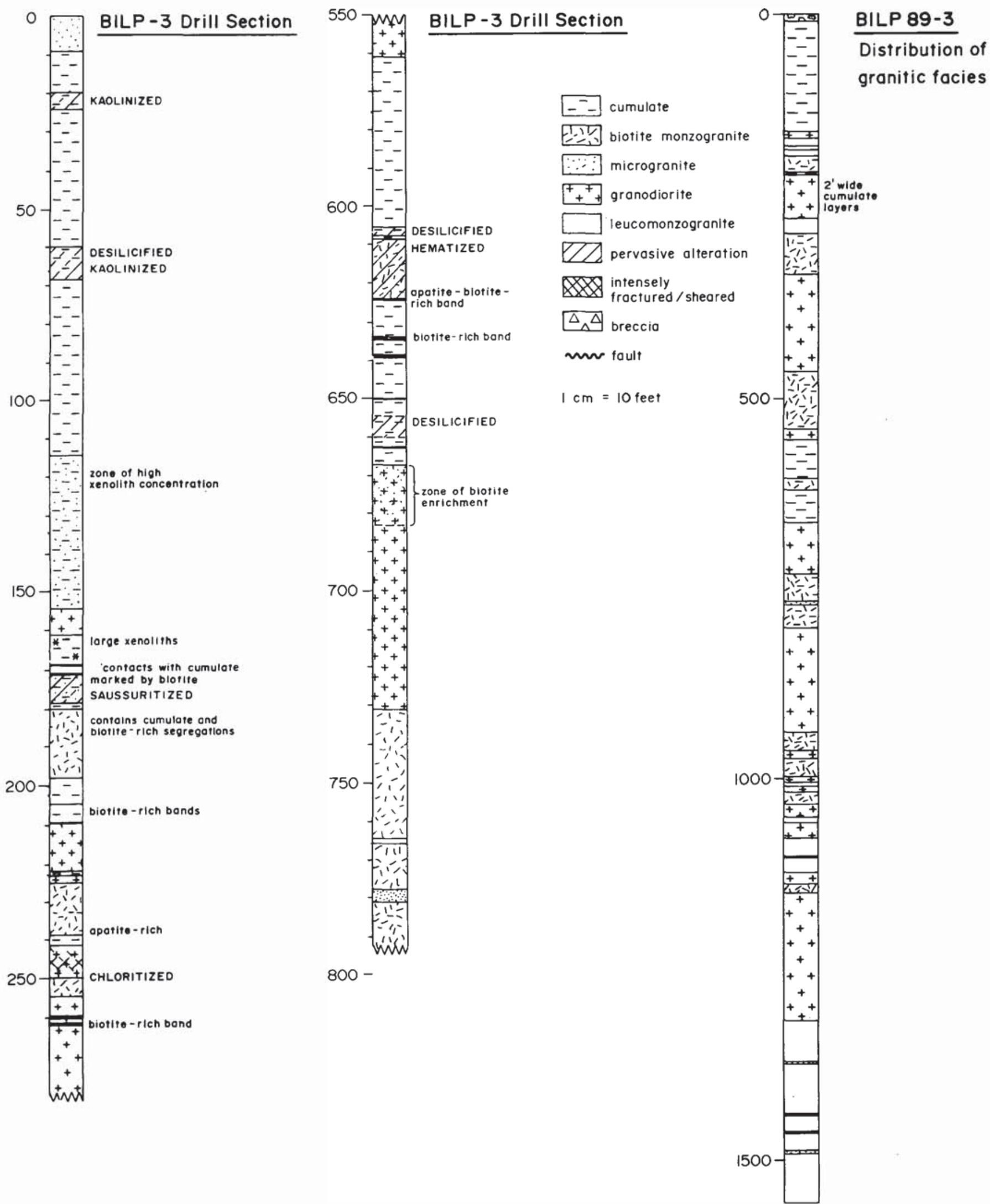

Fig. 6. Representative core sections from BILP-3 drill hole and section showing the distribution of granite-facies within the BILP-3 drill core. 
sharp and in some instances marked by biotite bands or chilled margins. Alteration observed within the biotite monzogranite includes hematization, chloritization and saussuritization.

The leucomonzogranite from this hole is predominately medium- to coarse-grained, equigranular with minor porphyritic sections and may display intense chloritization and argillic alteration. Although garnet is not a common accessory mineral within this facies, it can be locally abundant as shown within a porphyritic section from 81 to $86 \mathrm{~m}$ (265-283 $\mathrm{ft}$ ) which contains garnets associated with distinct biotitefree haloes. Other garnet-rich sections within this facies include a $10 \mathrm{~cm}$ wide zone at $342 \mathrm{~m} \mathrm{(1122} \mathrm{ft)} \mathrm{and} \mathrm{at} 465 \mathrm{~m}$ $(1525 \mathrm{ft})$ where a $1 \mathrm{~m}$ section occurs intercalated with biotiterich bands (Fig. 6).

Occurrences of microgranite within this hole are restricted to narrow ( $<1 \mathrm{~m})$ intersections (dykes?) within biotite monzogranite and leucomonzogranite. The microgranite shows similar characteristics to those described from the above drill holes. One exception is that the microgranite from this hole contains smaller $(<3 \mathrm{~mm})$, but more abundant garnet (Fig. 7).

Overall this hole shows a general sequence from thick, massive plagioclase-rich aggregate at the top of the hole becoming progressively less thick and less common to where it disappears at $190 \mathrm{~m}(624 \mathrm{ft})$; at this point granodiorite and biotite monzogranite dominate down to approximately $351 \mathrm{~m}$ $(1150 \mathrm{ft})$ where leucomonzogranite and microgranite become the dominate facies. The bottom $61+\mathrm{m}(200+\mathrm{ft})$ of core comprises massive leucomonzogranite interspersed with minor microgranite (Fig. 6).

\section{Discussion}

Features such as faulted contacts with the granodiorite country rock and brittle-ductile deformation in all drill holes indicate that structure was an integral component to emplacement of the Big Indian Lake pluton. Drill hole BILP-2 in particular shows intense deformation such as breccia and mylonite bands over its entire length. The fact that in many cases granodiorite intersections within this hole show intense ductile deformation while the surrounding Big Indian Lake pluton-facies show brittle deformation is curious and suggests that the former was subjected to higher temperature and/or pressure. These brittle-ductile zones also appear to have acted as conduits for successive and superimposed alteration and related mineralization (Corey and Chatterjee, 1990).

The drill core observations described in this paper indicate that the Big Indian Lake pluton possesses several unique features which separate it from other plutons within the batholith (MacDonald et al., 1992). Perhaps the most significant feature is the occurrence of the plagioclase-rich rock characterized by a framework of touching and often interlocking, plagioclase euhedra comprising 50 to $90 \%$ of the rock. These crystals are commonly zoned, may be poikilitic and often show well-developed growth textures at their

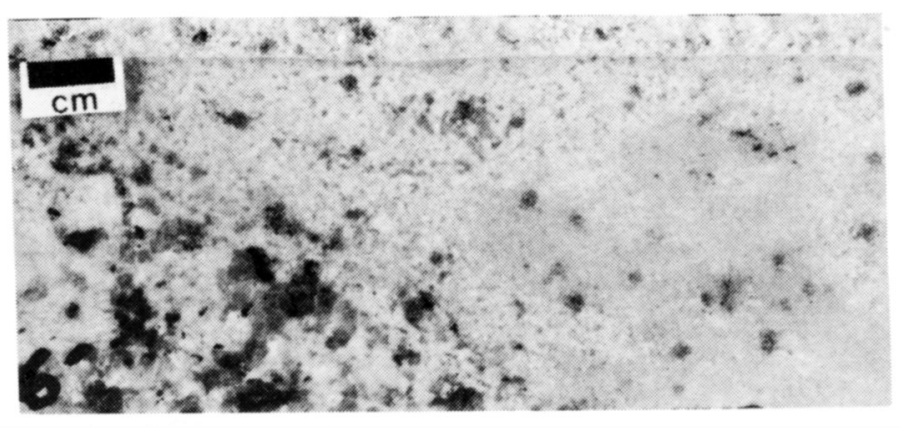

Fig. 7. Core sample showing garnet-bearing microgranite dyke (right) in sharp contact with biotite monzogranite.

margins. The presence of biotite as poikilitic inclusions within many of the plagioclase crystals suggests it co-crystallized with the plagioclase. Based on terminology defined by Irvine (1987), this rock-type is texturally similar to a cumulate. The presence of sub-horizontal layers of biotite and apatite enrichment within the aggregate also suggests that a similar process of crystal accumulation also affected these minerals. Biotite banding was also observed within the granodiorite where it occurs as $<10 \mathrm{~cm}$ thick bands oriented approximately $40^{\circ}$ from horizontal. Metasomatic banding also occurs, as reflected by alternating biotite-rich and biotite-free, garnet-bearing layers within leucomonzogranite and microgranite in BILP-3. This is consistent with a metasomatic origin for garnet within the pluton as suggested by Kontak and Corey (1988).

The presence of intensely saussuritized, chloritized and desilicified vuggy sections of the proposed-cumulate rock indicate that it was likely affected by alteration. It is not known if the metasomatising fluids responsible for these affects were derived from within the magma chamber or external to it. The presence of a narrow aplite dyke at a biotite monzogranite-cumulate rock contact may reflect late- to post-magmatic infiltration of fluid (residual?) along lithological contacts.

Perhaps the most puzzling aspect of the cumulate rock is that it occurs at the current level of exposure which, based on field observations, is suggested to represent the roof of the pluton. Conventional wisdom would suggest that due to a higher specific gravity such material should be situated near the floor of the chamber via a process of crystal-settling. While perhaps rare within peraluminous granites, this phenomena of inverse-grading has been observed within layered mafic plutons. Although several mechanisms (see Parsons, 1987) have been advanced to account for such a feature, the relevance of any one process to the Big Indian Lake pluton is at present speculation and more detailed study is required.

The observed interlayering of the cumulate rock with biotite monzogranite and granodiorite and gradational contacts between them suggests that these phases do not have intrusive contacts, but instead reflect compositional layering. The granodiorite may, however, have another source as suggested by the presence of similarly-textured granodiorite country rock into which the pluton was emplaced. In this case 
the granodiorite could represent roof blocks stoped from the surrounding Five Island Lake pluton. However, no evidence of mineral foliation within what would be the host rock at the margins in contact with granodiorite was observed as would be expected if the granodiorite sank through the crystallizing magma. The presence of common to abundant, small $(<25$ $\mathrm{cm}$ ) biotite-rich xenoliths of assumed metasedimentary origin within cumulate rock intersections is also curious since, like the plagioclase crystals, these blocks should sink through the melt due to their higher specific gravity. Such a process has been suggested to account for the general lack of xenoliths within rocks of the South Mountain Batholith. The occurrence of abundant xenoliths within the cumulate rock from 35 to $47 \mathrm{~m}(115-155 \mathrm{ft})$ may indicate that although they began to sink they were either supported by the plagioclase crystals or became frozen during rapid solidification of the plagioclase-rich aggregate. Another peculiar aspect of the proposed cumulate rock is the fact that it was intersected in only the one hole. This, together with the absence of similar outcrops elsewhere within the pluton, suggests that this particular process of crystal accumulation was restricted in scope due to a variety of reasons not appropriate for discussion in this paper. This is not to say that other cumulate-like segregations (piles) do not occur at different elevations within the pluton, or at other outcrops still to be discovered within the pluton.

The origin of the microgranite is another area which requires study. Its frequent syenogranite composition and close association with several types of alteration and mineralization as well as the common occurrence of pegmatite at facies boundaries within the drill core, indicates that the microgranite crystallized from a highly fractionated, watersaturated liquid. These features and the transition from microgranite at surface to leuco-monzogranite at depth in BILP1 suggests that the microgranite-facies may represent a texturally and mineralogically modified leucomonzogranite rather than a primary magmatic phase. Such a derivation would also explain the absence within microgranite of the intense fracturing and shearing noted in the leucomonzogranite in BILP1.

These problems and more are being addressed by a current detailed petrographic and geochemical study.

\section{Conclusions}

Diamond-drilling within the Big Indian Lake pluton has revealed many interesting geological features that include intense brittle-ductile deformation, extensive textural and mineralogical modification in response to successive and superimposed metasomatism, and compelling textural evidence suggesting igneous layering. The latter is reflected by the presence of a proposed plagioclase-biotite cumulate phase and prominent biotite and apatite layering. If corroborated by the current investigations, this would be the first occurrence of cumulate rock within the South Mountain Batholith and would be one of few documented within peraluminous granites.
The transition from plagioclase-rich aggregate at the surface to microgranite at depth within drill hole BILP-3 suggests that some process of compositional grading occurred within this portion of the magma chamber. The drill core further indicates that the plagioclase aggregate was affected by late- to post-magmatic metasomatism possibly attributed to interaction with highly-fractionated residual fluids.

These drill holes provide an excellent opportunity to study many unique features within the Big Indian Lake pluton as well as contribute to our understanding of the petrogenesis of the South Mountain Batholith and the occurrence of layering within peraluminous granites. Detailed petrographic and geochemical studies are currently in progress in order to determine the origin and significance of the aforementioned features.

\section{ACKNOWLedgements}

I would like to thank George O'Reilly, Dan Kontak, Brendon Murphy and an anonymous reviewer for their careful reviews and comments. Any remaining errors or omissions are the sole responsibility of the author. The paper also benefited from discussions with Dr. A.K. Chatterjee whose support for this study is appreciated. This project was funded by the 1985-1990 Canada-Nova Scotia Mineral Development Agreement.

Аввотт JR., R.N. 1989. Internal structures in part of the South Mountain batholith, Nova Scotia, Canada. Geological Society of America Bulletin, 101, pp. 1493-1506.

Corey, M.C. 1986. Bedrock Geology of the South Mountain Batholith: NTS Map Sheet 11D/13. In Mines and Minerals Branch, Report of Activities, 1985. Edited by J.L. Bates. Nova Scotia Department of Mines and Energy, Report 86-1, pp. 137-147.

1988. An occurrence of metasomatic aluminosilicates related to high alumina hydrothermal alteration within the South Mountain Batholith, Nova Scotia. Maritime Sediments and Atlantic Geology, 24, pp. 83-95.

1991. Diamond-drilling of the Big Indian Lake polyphase intrusive suite, Hants County, Nova Scotia (NTS Map 11D/ 13). Nova Scotia Department of Mines and Energy, Open File Report 91-003.

Corey, M.C. and Chatterjee, A.K. 1990. Characteristics of REE and other trace elements in response to successive and superimposed metasomatism within a portion of the South Mountain Batholith, Nova Scotia, Canada. Chemical Geology, 85 , pp. 265-285.

Ha M, L.J. and Horne, R.J. 1986. Geology of the South Mountain Batholith on the eastern half of NTS Map Sheet $21 \mathrm{~A} / 16$. In Mines and Minerals Branch, Report of Activities 1985. Edited by J.L. Bates. Nova Scotia Department of Mines and Energy, Report 86-1, pp. 149-159.

Horne, R.J., Corey, M.C., Ham, L.J., and MacDonald, M.A. 1991. Variation in the mafic mineral content of the Scrag Lake pluton, South Mountain batholith: evidence for a zoned pluton. In Mines and Minerals Branch, Report of Activities 1990. Edited by D.R. MacDonald. Nova Scotia Department 
of Mines and Energy, Report 91-1, pp. 49-60.

IRvine, T.N. 1987. Glossary of terms for layered intrusions. In Origins of Igneous Layering. Edited by I. Parsons. D. Reidel Publishing Company, pp. 641-647.

Kontak, D.J. and Corey, M.C. 1988. Metasomatic origin for spessartine-rich garnet in the South Mountain Batholith, Nova Scotia. Canadian Mineralogist, 26, pp. 315-334.

MacDonald, M.A., Horne, R.J., Corey, M.C., and Ham, L.J. 1992. An overview of recent bedrock mapping and follow-up petrological studies of the South Mountain Batholith, south- western Nova Scotia, Canada. Atlantic Geology, 28, pp. 728.

Parsons, I. (Editor) 1987. Proceedings of the NATO research workshop on origins of igneous layering, Narsarsuaq, South Greenland, August 4-15, 1986. D. Reidel Publishing Company.

SMITh, T.E. 1975. Layered granitic rocks at Chebucto Head, Halifax County, Nova Scotia. Canadian Journal of Earth Sciences, 12 , pp. $456-463$. 